\title{
Impact of social protection programs on adults diagnosed with Tuberculosis: systematic review
}

\author{
Impacto dos programas de proteção social em pessoas adultas com diagnóstico de Tuberculose: revisão sistemática
}

Impacto de los programas de protección social en adultos diagnosticados con Tuberculosis: revisión sistemática

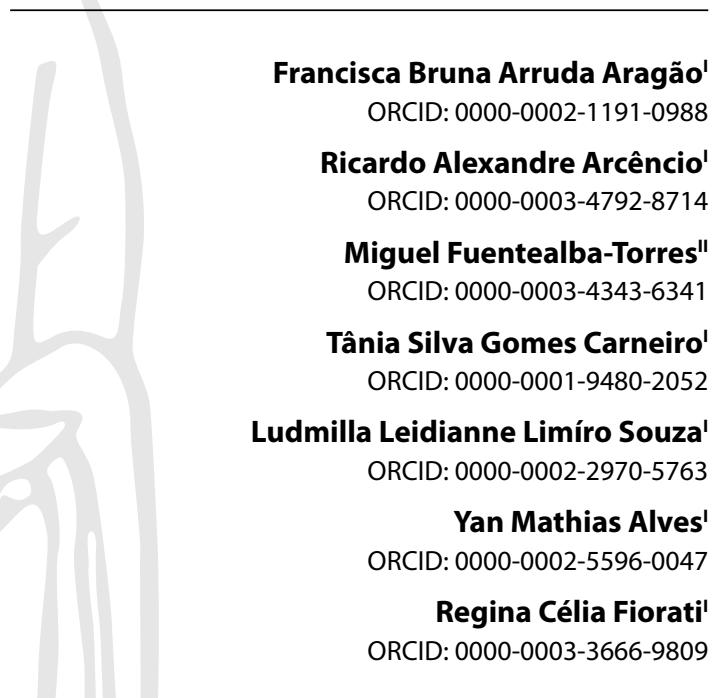

'Universidade de São Paulo. Ribeirão Preto, São Paulo, Brazil. "Universidad de los Andes. Santiago, Chile.

How to cite this article: Aragão FBA, Arcêncio RA, Fuentealba-Torres M, CarneiroTSG, Souza LLL, Alves YM, et al. Impact of social protection programs on adults diagnosed with Tuberculosis: systematic review. Rev Bras Enferm. 2021;74(3):e20190906. https://doi.org/10.1590/0034-7167-2019-0906

Corresponding author: Francisca Bruna Arruda Aragão E-mail:aragao_bruna@usp.br

EDITOR IN CHIEF: Dulce Barbosa ASSOCIATE EDITOR: Mitzy Reichembach

\begin{abstract}
Objectives: to analyze the impact of social protection programs on adults diagnosed with Tuberculosis. Methods: systematic review conducted by PRISMA, with registration PROSPERO CRD42019130884. The studies were identified in the VHL, PubMed, Scielo, CINAHL and Scopus databases, using the descriptors "Social Protection" and "Tuberculosis", in combination with keywords combined with Boolean operators AND and OR. Observational and interventional studies published until October 23, 2019, in Portuguese, English and Spanish, were included. Results: social protection programs improve the treatment of tuberculosis, cure rates, adherence to treatment, the provision of services for the control of TB and reduce poverty. Conclusions: social protection programs have a positive impact on the treatment and control of people diagnosed with Tuberculosis.

Descriptors: Tuberculosis; Social Protection; Treatment; Government Program; Systematic Review.
\end{abstract}

\section{RESUMO}

Objetivos: analisar o impacto dos programas de proteção social em pessoas adultas com diagnóstico de Tuberculose. Métodos: revisão sistemática conduzida pelo PRISMA, com registro PROSPERO $n^{\circ}$ CRD42019130884. Os estudos foram identificados nas bases de dados BVS, PubMed, Scielo, CINAHL e Scopus, a partir dos descritores "Proteção Social" e "Tuberculose", em combinação com palavras-chave combinadas com operadores booleanos $A N D$ e $O R$. Incluíram-se estudos observacionais e de intervenção, publicados até o dia 23 de outubro de 2019, nos idiomas português, inglês e espanhol. Resultados: os programas de proteção social melhoram o tratamento da Tuberculose, as taxas de cura, a aderência ao tratamento, a prestação de serviços para o controle da TB, além de reduzirem a pobreza. Conclusões: os programas de proteção social impactam de forma positiva no tratamento e controle das pessoas com diagnóstico de Tuberculose.

Descritores: Tuberculose; Proteção Social; Tratamento; Programas Governamentais; Revisão Sistemática.

\section{RESUMEN}

Objetivos: analizar el impacto de los programas sociales de adultos con diagnóstico de Tuberculosis. Métodos: se trata de una revisión sistemática conducida por PRISMA, con registro PROSPERO $\mathrm{n}^{\circ}$ CRD42019130884. Los estudios se identificaron en las bases de datos BVS, PubMed, Scielo, CINAHL y Scopus, a partir de los descriptores "Protección Social" y "Tuberculosis", y palabras clave combinadas con operadores booleanos AND y OR. Estaban incluidos los estudios observacionales y de intervención, publicados hasta el día 23 de octubre de 2019, en los idiomas portugués, inglés y español. Resultados: los programas de protección social mejoran el tratamiento de la tuberculosis, las tasas de curación, la adhesión al tratamiento, la prestación de servicios para el control de la TB, además de reducir la pobreza. Conclusiones: los programas sociales tienen un impacto positivo en el tratamiento y control de las personas diagnosticadas de tuberculosis.

Descriptores: Tuberculosis; Protección Social; Tratamiento; Programas Gubernamentales; Revisión Sistemática. 


\section{INTRODUCTION}

Tuberculosis (TB) is a public health problem with a global impact. In 2018, around ten million people worldwide became ill with tuberculosis, causing 1.5 million deaths ${ }^{(1)}$. In Brazil, in 2018, 73,864 new TB cases were registered, showing an incidence coefficient of 35.0 cases $/ 100$ thousand inhabitants and 4,490 deaths ${ }^{(2)}$.

The literature ${ }^{(2)}$ indicates that there is a strong relationship between TB and the living conditions of people with the disease, implying an increasing tendency to carry out studies that address the relationships between health and economic, social, and environmental factors, among others. In this sense, TB is associated with social determinants of health, and mortality and incidence occur with greater magnitude in low-income countries, with greater social vulnerability, inequality, poverty, little policy development and less social protection ${ }^{(2-3)}$.

In countries like Brazil, TB mortality and incidence are higher among people with low education and in poverty (odds ratio [OR]: 2,92; confidence interval of $95 \%[95 \% \mathrm{Cl}]: 1,17-7,28)^{(4)}$. For this reason, social protection programs can positively impact the reduction of social vulnerability and contribute to the World Health Organization's End-TB strategy, which seeks to reduce global TB mortality by 2035 and eliminate this disease in 2050)(5).

Due to the relationship between TB and the situation of social vulnerability resulting from poverty ${ }^{(6-14)}$, some low-income countries have created social protection programs to intervene in the health social determinants related to TB incidence and mortality. Some studies have shown positive results regarding disease control, treatment adherence and increased cure rates ${ }^{(2-3)}$, proving that social protection programs reduce social vulnerability and improve expectations of cure (6-14). $^{(2)}$

Although the studies available with a specific focus on the impact of social protection policies on people with TB are heterogeneous and limited, there are currently no records of previous systematic reviews, developed to globally analyze the effect of social protection policies on people with TB.

\section{OBJECTIVES}

To analyze the impact of social protection programs on adults diagnosed with Tuberculosis.

\section{METHODS}

The study consists of a systematic review registered in PROSPERO and under the number CRD42019130884. It was built according to preferred reporting items for systematic reviews and meta-analysis (PRISMA, for its acronyms in English) ${ }^{(15)}$, including the PRISMA checklist and the prisma Flowchart Diagram ${ }^{(16)}$.

\section{Eligibility criteria}

Studies have been included to address the following issue: What is the impact of social protection programs on adults diagnosed with tuberculosis? This question was formulated following the $\mathrm{PIO}$ structure ${ }^{(17)}(\mathrm{P}=$ Population, $\mathrm{I}=$ Intervention or exposure, $\mathrm{O}$ $=$ Outcomes) (Chart 1).
Chart 1 - Components of the research question, according to PIO acronym

\begin{tabular}{|c|c|c|}
\hline Description & Abbreviation & Research components \\
\hline Population & $\mathrm{P}$ & $\begin{array}{c}\text { Adult patients diagnosed with } \\
\text { Tuberculosis }\end{array}$ \\
\hline $\begin{array}{c}\text { Intervention or } \\
\text { exposure }\end{array}$ & $\mathrm{I}$ & $\begin{array}{c}\text { Exposure to social protection } \\
\text { programs }\end{array}$ \\
\hline Outcomes & $\mathrm{O}$ & $\begin{array}{c}\text { Impact of social protection in } \\
\text { the treatment of tuberculosis }\end{array}$ \\
\hline
\end{tabular}

Participants are made up of people adults (18 years of age or older) diagnosed with TB, regardless of comorbidities, exposed to a social protection program, for a minimum of six months and a maximum of two years. Observational (descriptive, cohort and cross-sectional) and intervention (quasi-experimental and controlled trials) studies were included, which showed quantitative data on the impact of social protection programs on adults diagnosed with TB. Primary studies in Portuguese, English and Spanish were included, with no time limit, and studies focused on social protection programs for nursing homes or other types of intramural institutions were excluded.

The sources of information consulted were Virtual Health Library (VHL), National Library of Medicine National Institutes of Health (PubMed), Scientific Electronic Library Online o Biblioteca Científica Electrónica en Línea (SciELO), Scopus and Cumulative Index to Nursing and Allied Health Literature (CINAHL).

The search strategies were developed for each base with the help of a specialized librarian. The Boolean operators AND and OR were used in combination with the descriptors Medical Subject Headings (MeSH) and Emtree Terms, in addition to Health Sciences Descriptors (DeCS), according to each database. The general strategy included the descriptors "Tuberculosis" AND ("Social Protection" OR "Government Programs" OR "Benefit, Social"), which were combined with keywords consisting of synonyms. The last search was carried out on October 23, 2019.

The recovered records were imported into the Software Rayyan ${ }^{(18)}$, eliminating duplicates to develop a database with the titles and abstracts of each record. The potentially eligible studies were identified by two independent reviewers (FBAA, TSG), after reading the titles and abstracts. The third reviewer (YMA) arbitrated the differences. Subsequently, the potentially eligible studies were read in full text by two independent reviewers (FBAA, TSG) and the third reviewer (YMA) again arbitrated the differences. The result of this process was summarized in the Prisma Flowchart (Figure 1).

Data were collected independently by pairs of four researchers: FBAA, TSG and YMA, LLLS. The divergences were discussed by the whole team until a consensus was established. In the process, a standardized extraction form was used to obtain the following information: 1) author, 2) year of publication, 3) country, 4) study design, 5) study objective, 6) level of evidence, 7) study sample, 8) source of study funding, 9) TB patient characteristics, 10) Tuberculosis treatment period, 11) name of the social program, 12) objective of the social program, 13) budget of the social program, 14) program results and 15) measures of associated effects (risk ratio or difference in means). 


\section{RESULTS}

A total of 440 records were evaluated according to eligibility criteria, after eliminating duplicates, until October 23, 2019. After reading the titles and abstracts, 17 articles were eligible and 423 were excluded because they were not focused on the topic. The reasons for exclusions were as follows: 75 did not include adult TB patients, 248 did not have exposure to social protection programs and 100 did not include information on social protection. When reading in full, of the 17 eligible articles, nine articles were included after applying the selection criteria (Figure 1).

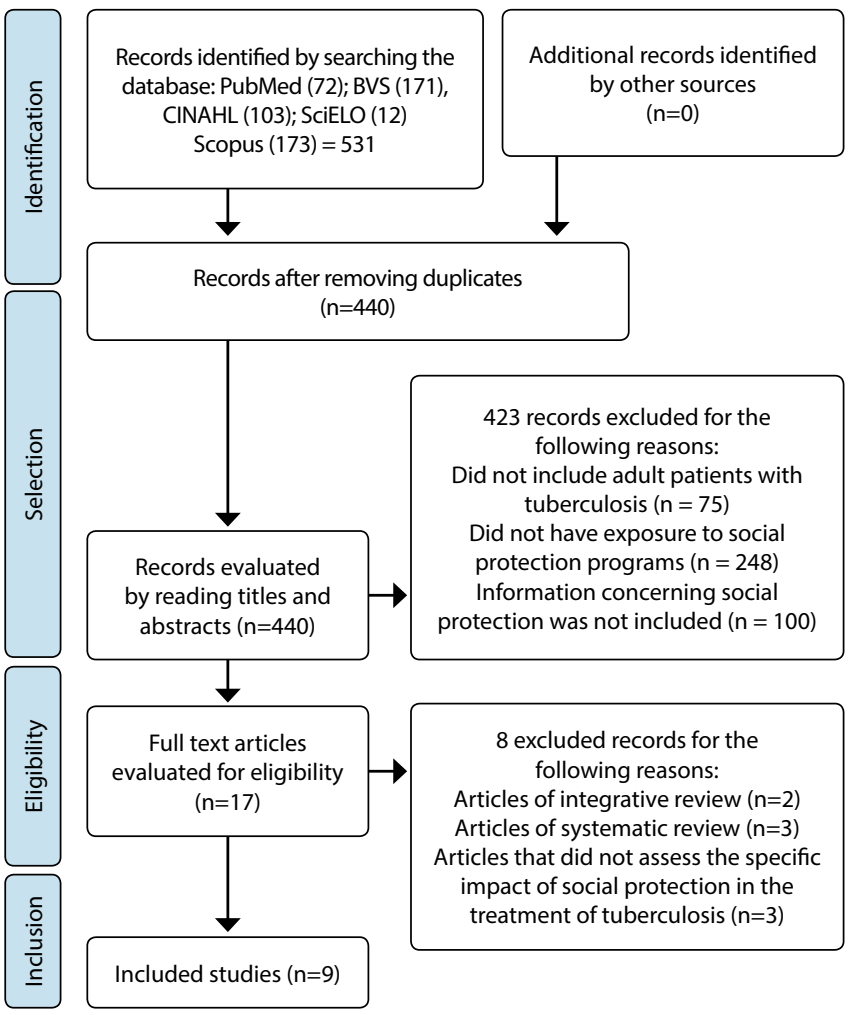

Figure 1 - Flowchart of the selecting articles process for review, according to PRISMA recommendation ${ }^{(15)}$

Regarding the characteristics of the included studies, they were developed in different regions of the world. Among the nine selected articles, four studies (36\%) were developed in Brazil(11-14), one $(11.1 \%)$ in Peru ${ }^{(10)}$, one $(11.1 \%)$ in India ${ }^{(6)}$, one $(11.1 \%)$ in Argentina ${ }^{(8)}$, one (11.1\%) in Indonesia ${ }^{(7)}$ and one (11.1\%) In South Africa ${ }^{(9)}$. Regarding the drawings, two studies were clinical trials $(22.2 \%)^{(9-10)}$, three studies were descriptive $(33.3 \%)^{(6-7,11)}$, one was almost experimental $(11.1 \%)^{(12)}$, one was longitudinal $(11.1 \%)^{(13)}$, one was a retrospective cohort $(11.1 \%)^{(14)}$ and one study was a prospective cohort $(11.1 \%)^{(8)}$. In terms of production period, the studies cover the years 2013 to 2019: one in $2013(11.1 \%)^{(9)}$, one in $2016(11.1 \%)^{(17)}$, one in $2017(11.1 \%)^{(10)}$, two in $2018(22.2 \%)^{(6,11)}$ and four in 2019 (44.44\%) $)^{(7-8,12-13)}$.

The studies aim at two similar categories: assessing socioeconomic impact and the effectiveness of social benefits. In this sense, three studies $(33.3 \%)^{(13,15,10)}$ suggest that the impact of socioeconomic support for tuberculosis preventive therapy is associated with success in treating patients. In addition, six studies
$(66.6 \%)^{(6,8-9,11,13-14)}$ determined that the incentive of social benefits can enable the effectiveness of providing economic support to patients with pulmonary TB.

Study samples vary between 25 and 25,084 TB patients. A study $(11.1 \%)^{(8)}$ comprised all patients diagnosed with TB pulmonary disease, sensitive TB and assistance to intervention clinics in the years 2009 and 2010 . A survey $(11.1 \%)^{(10)}$ made it possible to treat 312 families that had TB patients and recruited 90\% (282/312), of which 135 households were randomized to the intervention arm and 147 to the control arm. A study $(11.1 \%)^{(11)}$ worked with 131 people: six patients did not complete a month of treatment, five did not consent to participate in the research and one was excluded from the analysis, due to implausible income data. A survey $(11.1 \%)^{(12)}$ included 13029 individuals, of whom 6940 received the Bolsa Familia Program. A study $(11,1 \%)$ included 25084 individuals, of which only 5.993 (24\%) completed all the information in the data set. A study $(11.1 \%)^{(14)}$ had a sample of 5788 individuals, who received monetary benefits from the Bolsa Família Program. Finally, a study $(11.1 \%)^{(6)}$ included 1159 records and comprised 282 TB patients and 64 MDR-TB.

The social programs were diverse. According to the application countries and the amount of money, they approximately invested a minimum of 15 \$USD and a maximum of 725 \$USD monthly, with an average of 199,29 \$USD. Three out of nine studies (33.3\%) were associated with a positive effect of the social protection program while there is clinical improvement in TB. Such studies have shown associations of success with TB treatment with results: $(\mathrm{P}=0.107)^{(9)}$; $(\mathrm{OR}: 1.6 ; 95 \% \mathrm{Cl}=1.0-2.6)$ increased the uptake of preventive therapy (ORa: $2.2 ; 95 \% \mathrm{Cl}=1.1-4.1)^{(12)} ;(95 \% \mathrm{Cl}=4.39$ to 16.77$)^{(12)}$. Two studies (22.2\%) were associated with an improvement in the cure rate, the successful cure of pulmonary TB representing 5.2\% greater cure among those exposed to the program $^{(14)}$ (Coefficient $\left.0.08 ; 95 \% \mathrm{Cl}=0.06-0.11\right)^{(13)}$. Four studies were associated with service delivery, poverty and TB control. In the bivariate analysis, the chances of single use of the RSBY pre-treatment assessment package in non-poor patients were $0.04[(95 \% \mathrm{Cl}=0.02-0.07 ; p<0,0001)]$ times lower compared to the poor ${ }^{(6)}$, and this association remained statistically significant in the multivariate analysis [Odds ratio: $0.03,95 \% \mathrm{Cl}=0.01-0.05$ ). The social protection program impacts on the following factors: the risk of poverty has decreased $(p=0.002)^{(11)}$; met the need for food, transportation and income (median US \$ 205 [IQR 121] vs US $\$ 75$ (IQR 112); $P<0,001)^{(7)}$; helped control TB (odds ratio $(\mathrm{OR})$ for the success was $2.9(95 \% \mathrm{Cl}=2.0-4.3 ; P<0,001)$ and the standard was $0.36(95 \% \mathrm{Cl}=0.23-0.57 ; P<0.001)^{(14)}$.

For the evidence level (Chart 4), we used the model suggested by Melnyk e Fineout-Overholt ${ }^{(19)}$, which classifies trails in seven levels: Level I-evidence from systematic review or meta-analysis of all randomized controlled clinical trials, or from clinical guidelines based on systematic reviews of randomized controlled clinical trials; Level II - evidence derived from at least one well-designed randomized controlled clinical trial; Level III - evidence obtained from well-designed clinical trials without randomization; Level IV - evidence from well-designed cohort and case-control studies; Level V - evidence from systematic review of descriptive and qualitative studies; Level $\mathrm{VI}$ - evidence derived from a single study descriptive or qualitative; Level VII - evidence from the opinion 
of authorities and/or expert committee reports. Regarding the quality of the evidence, the Mixed Method Appraisal Tool (MMAT) ${ }^{(20)}$ was used, created to evaluate the methodological quality of the most common types of study designs, being useful to evaluate quantitative and qualitative studies through specific criteria(20). The evaluation of the criteria is carried out by associating scores in the form of a percentage, with a minimum score equal to $25 \%$ and a maximum score equal to $100 \%$. In the quality assessment, each score is represented by the symbol "**", with a minimum of $25 \%$ "*" and a maximum of $100 \%$ "****" $(18,19)$ (Chart 5).

In the quality analysis, in the randomized controlled trials, all studies ${ }^{(9-10)}$ presented moderate quality and low withdrawal or dropout of cases, with controls in percentage not exceeding
$20 \%$. In the studies non-randomized quantitative, one out of four was suspected of high quality ${ }^{(12)}$, while three out of four were suspected of moderate quality ${ }^{(8,13-14)}$. Of these studies, two ${ }^{(8,14)}$ reported data with incomplete response rates in $60 \%$ of the cases, one ${ }^{(14)}$ showed dissimilarities and imbalance between the characteristics of the groups in $26.7 \%$ of the cases and one $e^{(13)}$ presented difficulties when using appropriate measures ${ }^{(13)}$. In the quantitative descriptive studies, one ${ }^{(6)}$ out of three studies had a suspicion of moderate quality due to the lack of randomization of the sample, while two out of three ${ }^{(7,11)}$ had low quality due to the lack of randomization of the sample, the unrepresentative sample size, measurement bias due to the use of non-validated measurement instruments and incomplete data.

Chart 2 - Characteristics of the studies included in the review

\begin{tabular}{|c|c|c|c|c|c|}
\hline Author, year & Country & Design & Study objectives & Funding source & Sample \\
\hline $\begin{array}{l}\text { Lutge, } \\
\text { Elizabeth } \\
2013\end{array}$ & $\begin{array}{l}\text { South } \\
\text { Africa }\end{array}$ & $\begin{array}{l}\text { Controlled, pragmatic, } \\
\text { not blind, randomized } \\
\text { by cluster }\end{array}$ & $\begin{array}{l}\text { Test the feasibility and effectiveness of the provision of } \\
\text { economic support for patients with pulmonary TB in a high- } \\
\text { burden province in South Africa. }\end{array}$ & Public funding & $\begin{array}{l}4.091 \text { people } \\
\text { (exposure } n=2.107 \\
\text { control } n=1.984 \text { ) }\end{array}$ \\
\hline $\begin{array}{l}\text { Wingfield }{ }^{(10)} \text {, } \\
\text { T, } 2017\end{array}$ & Peru & $\begin{array}{l}\text { Controlled, } \\
\text { randomized, not } \\
\text { blind }\end{array}$ & $\begin{array}{l}\text { Evaluate the impact of socioeconomic support in the initiation } \\
\text { of TB preventive therapy in home contacts of patients with } \\
\text { tuberculosis and in the success of treatment in patients. }\end{array}$ & Public funding & $\begin{array}{l}282 \text { people } \\
\text { (exposure } n=135 \\
\text { control } n=147 \text { ) }\end{array}$ \\
\hline $\begin{array}{l}\text { Kundu }^{(6)}, \mathrm{D}, \\
2018\end{array}$ & India & $\begin{array}{l}\text { Quantitative } \\
\text { descriptive }\end{array}$ & $\begin{array}{l}\text { Determine whether the implementation of MDR TB health } \\
\text { insurance packages is effective or not. }\end{array}$ & Public funding & 1159 people \\
\hline $\begin{array}{l}\text { Rudgard(11), } \\
\text { W.E, } 2018\end{array}$ & Brazil & $\begin{array}{l}\text { Quantitative } \\
\text { descriptive }\end{array}$ & $\begin{array}{l}\text { Assess whether the adoption of social protection during } \\
\text { treatment was associated with a reduced risk of financial } \\
\text { difficulties. }\end{array}$ & Public funding & 131 people \\
\hline $\begin{array}{l}\text { J Carter }{ }^{(12)}, \mathrm{D}, \\
2019\end{array}$ & Brazil & $\begin{array}{l}\text { Quasi-experimental } \\
\text { approach }\end{array}$ & $\begin{array}{l}\text { Estimate the impact of a conditional cash transfer program on } \\
\text { the success rates of TB treatment. }\end{array}$ & Public funding & $\begin{array}{l}13.029 \text { people } \\
\text { (exposure } n=1269 \\
\text { control } n=898 \text { ) }\end{array}$ \\
\hline $\begin{array}{l}\text { Reis-Santos } \\
\mathrm{B}, 2019\end{array}$ & Brazil & Longitudinal Study & $\begin{array}{l}\text { Evaluate the effect of being a beneficiary of a Brazilian } \\
\text { government cash transfer program, the Bolsa Familia Program } \\
\text { (PBF), on cure rates for TB treatment. }\end{array}$ & Public funding & 5.993 people \\
\hline $\begin{array}{l}\text { Fuady }{ }^{(7)}, A \\
2019\end{array}$ & Indonesai & $\begin{array}{l}\text { Descriptive } \\
\text { quantitative }\end{array}$ & $\begin{array}{l}\text { Measure the socioeconomic impact of TB and MDR-TB } \\
\text { (including the incidence of catastrophic costs) and assess the } \\
\text { perceived needs of patients for social protection in Indonesia. }\end{array}$ & Public funding & 282 people \\
\hline $\begin{array}{l}\text { Torrens }{ }^{(14)}, \\
\text { Ana W, } 2016\end{array}$ & Brazil & Retrospective cohort & $\begin{array}{l}\text { Inform the new policy, assessing the role of the PBF, one of the } \\
\text { largest conditional cash transfer programs in the world, on TB } \\
\text { cure rates in Brazil. }\end{array}$ & Public funding & $\begin{array}{l}7.255 \text { people } \\
\text { (exposure } n=5.788 \text {, } \\
\text { control } n=1.467 \text { ) }\end{array}$ \\
\hline $\begin{array}{l}\text { Klein }^{(8)}, \mathrm{K} \\
2019\end{array}$ & Argentina & Prospective cohort & $\begin{array}{l}\text { Assess the effect of a conditional cash transfer (CCT) policy on } \\
\text { treatment success and default rates in a prospective cohort of } \\
\text { socioeconomically disadvantaged patients. }\end{array}$ & Public funding & 941 people \\
\hline
\end{tabular}

Chart 3 - Characteristics of the social protection programs included in the review

\begin{tabular}{|c|c|c|c|c|c|}
\hline Author, year & $\begin{array}{c}\text { Period of } \\
\text { treatment for } \\
\text { Tuberculosis }\end{array}$ & $\begin{array}{l}\text { Social Program } \\
\text { budget }\end{array}$ & $\begin{array}{l}\text { Social } \\
\text { Program } \\
\text { Name }\end{array}$ & $\begin{array}{l}\text { Objective of the social } \\
\text { program }\end{array}$ & Results of the social protection program \\
\hline $\begin{array}{l}\text { Elizabeth } \\
\text { Lutge }^{(9)}, 2013\end{array}$ & $2009-2010$ & Approximately US\$ 15 & $\begin{array}{l}\text { Monthly } \\
\text { voucher }\end{array}$ & $\begin{array}{l}\text { Vouchers were redeemed at } \\
\text { local stores for food. }\end{array}$ & $\begin{array}{l}\text { It was associated with successful TB treatment } \\
(P<0.001) \text {, showing } 5.6 \% \text { less risk of failure in } \\
\text { the treatment of tuberculosis. }\end{array}$ \\
\hline $\begin{array}{l}\text { Wingfield }^{(10)} \text {, } \\
\text { T, } 2017\end{array}$ & $2014-2015$ & $\begin{array}{l}\text { Up to US\$ } 230 \text { per } \\
\text { family }\end{array}$ & $\begin{array}{l}\text { Peruvian } \\
\text { National } \\
\text { Tuberculosis } \\
\text { Program }\end{array}$ & $\begin{array}{l}\text { To access the complete } \\
\text { treatment in clinics. }\end{array}$ & $\begin{array}{l}\text { It was associated with } 2.2 \text { times more chances } \\
\text { of obtaining TB preventive therapy (ORa: } 2.2 ; \\
95 \% \mathrm{Cl}=1.1-4.1 \text { ) and } 1,6 \text { times more chances } \\
\text { of success in treating TB (OR: } 1.6 ; 95 \% \mathrm{Cl}= \\
1.0-2.6) \text {. }\end{array}$ \\
\hline $\begin{array}{l}\text { Kundu(6), D, } \\
2018\end{array}$ & $2013-2015$ & $\begin{array}{l}\text { US\$ } 500 \text { per family in } \\
\text { one year } \\
\text { (up to } 5 \text { members in a } \\
\text { family). }\end{array}$ & $\begin{array}{l}\text { Universal } \\
\text { health } \\
\text { insurance }\end{array}$ & $\begin{array}{l}\text { To access treatment } \\
\text { for multidrug-resistant } \\
\text { tuberculosis (MDRTB) in India. }\end{array}$ & $\begin{array}{l}\text { It was associated with } 0.3 \text { times more chances } \\
\text { of using a single pre-treatment evaluation } \\
\text { package with } \mathrm{RSBY}^{*} \text { (ORa: } 0.03 ; 95 \% \mathrm{Cl}= \\
0.01-0.05) \text {. }\end{array}$ \\
\hline $\begin{array}{l}\text { Rudgard(11), } \\
\text { W.E, } 2018\end{array}$ & 2016 & $\begin{array}{l}\text { USD } 1970 \pm 2897 \\
\text { (Annual). }\end{array}$ & Bolsa Família & $\begin{array}{l}\text { It is a direct income transfer } \\
\text { program, aimed at families in } \\
\text { situations of poverty. }\end{array}$ & $\begin{array}{l}\text { It was associated with } 1.31 \text { times less risk of } \\
\text { poverty (RR: } 1.31 ; 95 \% \mathrm{Cl}=0.50-3.47) \text {. }\end{array}$ \\
\hline
\end{tabular}


Chart 3 (concluded)

\begin{tabular}{|c|c|c|c|c|c|}
\hline Author, year & $\begin{array}{l}\text { Period of } \\
\text { treatment for } \\
\text { Tuberculosis }\end{array}$ & $\begin{array}{l}\text { Social Program } \\
\text { budget }\end{array}$ & $\begin{array}{l}\text { Social } \\
\text { Program } \\
\text { Name }\end{array}$ & $\begin{array}{l}\text { Objective of the social } \\
\text { program }\end{array}$ & Results of the social protection program \\
\hline $\begin{array}{l}\text { J Carter }{ }^{(12)}, \mathrm{D}, \\
2019\end{array}$ & 2010-2011 & $\begin{array}{l}\mathrm{R} \$ 70 \text { to } \mathrm{R} \$ 140 \text { per } \\
\text { month. }\end{array}$ & $\begin{array}{l}\text { Bolsa Família } \\
\text { Program }\end{array}$ & $\begin{array}{l}\text { It is a direct income transfer } \\
\text { program, aimed at families in } \\
\text { situations of poverty. }\end{array}$ & $\begin{array}{l}\text { It was associated with a } 10.58 \% \text { higher } \\
\text { success rate in treating TB. }\end{array}$ \\
\hline $\begin{array}{l}\text { Reis- } \\
\text { Santos }^{(13)}, \mathrm{B}, \\
2019\end{array}$ & 2015 & $\begin{array}{l}\mathrm{R} \$ 70 \text { to } \mathrm{R} \$ 140 \text { per } \\
\text { month. }\end{array}$ & $\begin{array}{l}\text { Bolsa Familia } \\
\text { Program }\end{array}$ & $\begin{array}{l}\text { It is a direct income transfer } \\
\text { program, aimed at families in } \\
\text { situations of poverty. }\end{array}$ & $\begin{array}{l}\text { It was associated with an } 8 \% \text { increase in the } \\
\text { successful cure of pulmonary TB (Coefficient: } \\
0.08 ; 95 \% \mathrm{Cl}=0.06-0.11)\end{array}$ \\
\hline $\begin{array}{l}\text { Fuady }^{(7)}, A \\
2019\end{array}$ & 2016 & $\begin{array}{l}\text { US\$ } 4 \text { to US\$ } 205 \text { per } \\
\text { month. }\end{array}$ & $\begin{array}{l}\text { General } \\
\text { Cash } \\
\text { Transfer }\end{array}$ & $\begin{array}{l}\text { Financial support to cover } \\
\text { costs related to lost income, } \\
\text { transportation and food } \\
\text { supplements. }\end{array}$ & $\begin{array}{l}\text { It was associated with a greater economic } \\
\text { need in the income of patients with } \\
\text { multidrug-resistant TB. }(P<0.001) \text {. }\end{array}$ \\
\hline $\begin{array}{l}\text { Torrens }^{(14)}, \\
\text { Ana W, } 2016\end{array}$ & 2010-2011 & $\begin{array}{l}\text { Average value } \\
\text { US\$55,60 monthly. }\end{array}$ & Bolsa Família & $\begin{array}{l}\text { It is a direct income transfer } \\
\text { program, aimed at families in } \\
\text { situations of poverty. }\end{array}$ & $\begin{array}{l}\text { It was associated with the } 5.2 \% \text { greater } \\
\text { chance of curing pulmonary TB (RR: } 1.07 ; 95 \% \\
\mathrm{Cl}=1.04-1.11 \text { ). }\end{array}$ \\
\hline $\begin{array}{l}\text { Klein }^{(8)}, \mathrm{K}, \\
2019\end{array}$ & 2 years & $\begin{array}{l}\text { The monthly family } \\
\text { income was collected in } \\
\text { categories: tertile } 1 \text { was } \\
\text { less than } 245 \text { and tertile } \\
2 \text { was from } 246 \text { to } 725 \text {. }\end{array}$ & $\begin{array}{l}\mathrm{CCT} \\
\text { Program }\end{array}$ & $\begin{array}{l}\text { Encourage complete } \\
\text { treatment. }\end{array}$ & $\begin{array}{l}\text { The program was associated with } 2.9 \text { times } \\
\text { more chance of TB control in the global } \\
\text { population (OR: } 2.9 ; 95 \% \mathrm{Cl}=2.0-4.3 \text { ). }\end{array}$ \\
\hline
\end{tabular}

Note: *RSBY - National Health Insurance Program, known as "Rashtriya Swasthya Bima Yojana".

Chart 4 - Description of the level of evidence of the included studies

\begin{tabular}{|c|c|}
\hline Study design & Evidence level of studies* \\
\hline \multicolumn{2}{|c|}{ Randomized Controlled Clinical Trial } \\
\hline Lutge, Elizabeth $2013^{(9)}$ & II \\
\hline Wingfield, T, 2017(10) & II \\
\hline \multicolumn{2}{|l|}{ Prospective cohort study } \\
\hline Klein, K, 2019(8) & IV \\
\hline \multicolumn{2}{|c|}{ Retrospective cohort study } \\
\hline Torrens ${ }^{(14)}$, Ana W, 2016 & IV \\
\hline \multicolumn{2}{|l|}{ Quantitative Descriptive } \\
\hline $\mathrm{Kundu}^{(6)}, \mathrm{D}, 2018$ & VI \\
\hline Fuady ${ }^{(7)}, A, 2019$ & $\mathrm{VI}$ \\
\hline Rudgard, W.E, 2018 & $\mathrm{VI}$ \\
\hline \multicolumn{2}{|l|}{ Quasi-Experimental Study } \\
\hline J Carter, D, 2019(12) & $\mathrm{VI}$ \\
\hline \multicolumn{2}{|l|}{ Longitudinal Study } \\
\hline Reis-Santos, B, $2019^{(13)}$ & VI \\
\hline
\end{tabular}

Note: *Level of evidence according to the model suggested by Melnyk e Fineout-Overholt ${ }^{(19)}$.

Chart 5 - Quality of studies included according to Mixed Method Appraisal Tool(20)

\begin{tabular}{|c|c|c|c|c|c|}
\hline \multirow{2}{*}{$\begin{array}{l}\text { Design and studies } \\
\text { Quantitative } \\
\text { Randomized } \\
\text { controlled trial (trials) }\end{array}$} & \multicolumn{5}{|c|}{ Evaluation Criteria } \\
\hline & $\begin{array}{l}\text { Randomization, } \\
\text { sequence } \\
\text { generation }\end{array}$ & $\begin{array}{l}\text { Allocation } \\
\text { Concealment }\end{array}$ & $\begin{array}{l}\text { Results complete data ( } 80 \% \\
\text { or more) }\end{array}$ & $\begin{array}{l}\text { Low removal / withdrawal } \\
\text { (below 20\%) }\end{array}$ & Comments \\
\hline Lutge, Elizabeth, 2013 & $* * * *$ & $* * * *$ & $* * * *$ & $* * *$ & $\begin{array}{l}\text { Moderate quality } \\
\text { is suspected }\end{array}$ \\
\hline Wingfield, T, 2017 & $* * * *$ & $* * * *$ & $* * * *$ & $* * *$ & $\begin{array}{l}\text { Moderate quality } \\
\text { is suspected }\end{array}$ \\
\hline $\begin{array}{l}\text { Quantitative no } \\
\text { randomized }\end{array}$ & $\begin{array}{l}\text { Minimum selection } \\
\text { biases }\end{array}$ & $\begin{array}{l}\text { Appropriate } \\
\text { measures }\end{array}$ & $\begin{array}{c}\text { Comparable study groups } \\
\text { or differences represented } \\
\text { by these groups }\end{array}$ & $\begin{array}{l}\text { Results data } 80 \% \text { or more, } \\
\text { response rate } 60 \% \text { or more, } \\
\text { or acceptable follow-up rate }\end{array}$ & Comments \\
\hline Klein, K, 2019(8) & $* * * *$ & $* * * *$ & $* * * *$ & $* * *$ & $\begin{array}{l}\text { Low quality is } \\
\text { suspected }\end{array}$ \\
\hline Torrens $^{(14)}$, Ana W, 2016 & $* * * *$ & $* * * *$ & $* * *$ & $* * *$ & $\begin{array}{l}\text { Low quality is } \\
\text { suspected }\end{array}$ \\
\hline J Carter, D 2019(12), & $* * * *$ & $* * * *$ & $* * * *$ & $* * * *$ & $\begin{array}{l}\text { High quality is } \\
\text { suspected }\end{array}$ \\
\hline Reis-Santos, B, 2019(13) & $* * * *$ & $* * *$ & $* * * *$ & $* * * *$ & $\begin{array}{l}\text { Low quality is } \\
\text { suspected }\end{array}$ \\
\hline
\end{tabular}




\begin{tabular}{|c|c|c|c|c|c|}
\hline \multirow{2}{*}{$\begin{array}{l}\text { Design and studies } \\
\text { Quantitative } \\
\text { Descriptive }\end{array}$} & \multicolumn{5}{|c|}{ Evaluation Criteria } \\
\hline & $\begin{array}{l}\text { Sampling strategy } \\
\text { relevant to the } \\
\text { research question }\end{array}$ & $\begin{array}{l}\text { Representative } \\
\text { sample of the } \\
\text { population }\end{array}$ & Appropriate measurements & $\begin{array}{l}\text { Response rates equal to or } \\
\text { greater than } 60 \%\end{array}$ & Comments \\
\hline Kundu $^{(6)}, \mathrm{D}, 2018$ & $* * *$ & $* * * *$ & $* * * *$ & $* * * *$ & $\begin{array}{l}\text { Moderate quality } \\
\text { is suspected }\end{array}$ \\
\hline Rudgard, W.E, 2018 ${ }^{(11)}$ & $* *$ & $* *$ & $* *$ & $* * *$ & $\begin{array}{l}\text { Low quality is } \\
\text { suspected }\end{array}$ \\
\hline Fuady ${ }^{(7)}, A, 2019$ & * & $* *$ & $* * *$ & * & $\begin{array}{l}\text { Low quality is } \\
\text { suspected }\end{array}$ \\
\hline
\end{tabular}

Note: Scores ranging from $25 \%\left({ }^{*}\right)$ - a criterion met at $100 \%\left(^{* * * *}\right)$ - all criteria met -, according to the Mixed Method Appraisal Tool (MMAT) ${ }^{(20)}$.

\section{DISCUSSION}

This systematic review aimed to analyze the impact of social protection programs on adults diagnosed with TB. The results demonstrated that there is a positive relationship between the improvement of TB patients and the receipt of social assistance, as it improves treatment, cure rates, treatment adherence, service provision, poverty and TB control. The PBF has three main pillars: income transfer, which makes it possible to alleviate poverty immediately; conditionalities, which reinforce the rights to health and education; and complementary programs, which seek to provide better living conditions for families ${ }^{(21)}$.

Of these investigated studies, the association of treatment improvement with social programs is represented among TB patients who receive PBF, since there was a success rate in treatment: 10.58 percentage points higher than those who did not receive the benefit. The proportion successfully treated in those who did not receive the PBF was $76.6 \%$, compared with $87.2 \%$ of the PBF beneficiaries ${ }^{(12)}$. Regarding treatment success, according to a study ${ }^{(22)}, 87$ non-adherent patients and 1302 adherents were interviewed. As for the main causes pointed out for the lack of treatment by non-adherent patients, there is the absence of money (30\%), the use of alcohol (30\%) and the fact that they do not perceive themselves as sick (25\%). Most preferred monetary incentives (67\%) followed by hot food or meals (41\%) and transportation reimbursement (32\%). Generally, with regard to the proposed social support programs, those that offered small daily incentives (23\%) or a relevant final bonus (21\%) were identified as being the most popular. Most patients (67\%) preferred outpatient treatment.

It should be noted that a specific socioeconomic support intervention for tuberculosis increased the uptake of preventive therapy against TB and the success in treatment. In the intention analysis, the success rate was $64 \%(87 / 135)$ in the intervention arm and 53\% (78/147) in the control $\mathrm{arm}^{(10)}$. Thus, in the analysis of a study ${ }^{(23)}$, we could identify an association between successful treatment with Social Protection Strategies (SPS) and TB and a decrease in risks in the lack of treatment and in therapeutic failure among patients under SPS. Such evidence supports the implementation of social support with universal health coverage, especially in situations of endemic TB or populations considered poor.

In Brazilian studies, it was analyzed that, in the income transfer group, the association social benefit and treatment contributed to the disappearance of the disease. This treatment effect confirmed that being a beneficiary of social programs improved TB cure rates by $8 \%$. According to a study ${ }^{(23)}$, because of the disease, people with TB face direct costs (expenses with transportation, exams, consultations and medications) and indirect costs (absence of work related to diseases) that can be reduced by the SPS.

Studies have shown that the relationship between TB treatment in health and social assistance has brought important benefits to the lives of people diagnosed with TB, interfering in the treatment. This reveals the importance of intersectionality in the treatment of socially determined health-disease processes, showing, therefore, that the articulation between health and social assistance has been accompanied by positive results in several countries reported by the studies analyzed. Andrade's study ${ }^{(23)}$ supported the arguments that social protection can favor the success of TB treatment, providing improvements, especially to adherence. To achieve the goals for the elimination of TB after 2015 , it depends on strengthening social protection among the priorities of the National Tuberculosis Programs (PNDs), considered as the main action. It became evident that low and middle income countries must extend health coverage in order to reach the poorest people, with effective social support, through income transfer mechanisms and comprehensive interventions that can positively impact relative results to TB.

Social protection policies and programs are identified by the World Health Organization (WHO) as an important element in addressing the social determinants of health $(\mathrm{SDH})$ and inequalities in health, operating in the sense of providing important changes in the material conditions of life, such as working conditions, housing, access to healthy food, access to transportation and health services, among others ${ }^{(24)}$. Social protection programs improve TB treatment, cure rates, adherence to treatment, provision of services for TB control and reduce poverty. Thus, in its conceptual framework on the social determinants of health, social protection is understood as a structural social determinant, intrinsically linked to the socioeconomic and political context of a country, being able to have repercussions on the daily lives of vulnerable social groups with positive impacts. the health of these groups and equity ${ }^{(24)}$.

WHO also points to the National Health Systems as a component of the Social Determinants of Health (SDOH) that operates directly on the health outcomes in the population, that is, the importance of public and universal health systems, with health as a right that has a positive impact in the quality of life and health gradient of the population ${ }^{(24)}$. In this direction, the synthesis of evidence ${ }^{(10,12)}$ points out that there is an urgent need to build a relationship between the public and private sectors 
to improve the provision of services to patients with MDR-TB in India, through a new insurance mechanism of health. Non-poor patients with MDR-TB were more able to access the private sector than the poor, for using claims in the pre-treatment assessment package for MDR-TB. These differences make them unequal and indicate a difficulty in guaranteeing the health promotion of MDR-TB through the benefit packages ${ }^{(12)}$.

The main social protection needs of patients to cover costs are related to loss of income, transportation and food supplements. In the research, it was expected that social benefits would be provided to remedy the difficulties presented above and that they would reduce the respective cost incidence in $11 \%$ and $23 \%$ of households affected by TB and MDR-TB ${ }^{(7)}$.

The studies analyzed in this review showed that the occurrences of TB in the respective countries are directly associated with the indicators of social vulnerability and the low living conditions of the population. In addition, in most of the analyzed researches, the success of treatment and prevention of those offered with social benefits is perceived. From this perspective, it became evident that there is a relationship between poverty and TB, about risk and effect. Although most countries provide TB drugs free of charge to TB patients, they still face high costs related to travel, food and nutritional supplements ${ }^{(7)}$.

\section{Study limitations}

The heterogeneity of the studies did not allow the combination of parameters to develop a meta-analysis. Further observational and intervention studies are needed to improve the quality and accuracy of the evidence synthesis.

\section{Contributions to the Nursing, Health or Public Policy fields}

Social protection programs help in the treatment of TB and act as facilitators of adherence, since most individuals affected by the disease have weaknesses in their ways of life and work. The knowledge obtained in this study shows health professionals, especially nursing team professionals who actively work in the treatment and control of the disease, the importance of carrying out work involving intersectionality/interdisciplinarity with social assistance and other sectors of public management together on the social determinants that impact on people diagnosed with TB, in order to minimize the social inequalities that impact on human health.

\section{CONCLUSIONS}

The incorporation of social protection programs, as well as public policies aimed at social equity, has a considerable effect on the control of the disease, indicated in its different countries of study. Social problems become aggravating to maintain the service of treatment and prevention of the referred countries.

Although the results of studies of systematic literature review on the insertion of social programs for the TB tuberculosis treatment are associated with the improvement of the disease occurrence, it is necessary to conduct further research due to the limited studies.

\section{ACKNOWLEDGMENT}

To Coordination for the Improvement of Higher Education Personnel (CAPES).

\section{REFERENCES}

1. Organização Mundial de Saúde (OMS). Relatório global sobre tuberculose [Internet]. 2019 [cited 2019 Apr 20]. Available from: https:// saudeamanha.fiocruz.br/oms-lanca-relatorio-global-sobre-tuberculose-2019/

2. Ministério da Saúde (BR). Secretaria de Vigilância em Saúde. Departamento de Doenças de Condições Crônicas e Infecções Sexualmente Transmissíveis - DCCl. Boletim Epidemiológico Especial [Internet]. Brasilia, DF: Editora MS/CGD, 2020 [cited 2020 Jul 20]. Available from: http://www.saude.gov.br/images/pdf/2020/marco/24/Boletim-tuberculose-2020-marcas--1-.pdf

3. Barreira D. Os desafios para a eliminação da tuberculose no Brasil. Epidemiol Serv Saúde. 2018;27(1):1-4. https://doi.org/10.5123/S1679 49742018000100009

4. Alves JD, Arroyo LH, Arcoverde MAM, Cartagena-Ramos D, Berra TZ, Alves LS, et. al. Magnitud de los determinantes sociales en el riesgo de mortalidad por tuberculosis en el Centro-Oeste de Brasil. Gac Sanit. 2020;34(2):171-8. https://doi.org/10.1016/j.gaceta.2019.01.004

5. World Health Organization (WHO). Global tuberculosis report [Internet]. 2017 [cited 2019 Apr 20]. https://reliefweb.int/report/world/ global-tuberculosis-report-2017

6. Kundu D, Sharma N, Chadha S, Laokri S, Awungafac G, Jiang L. Analysis of multi drug resistant tuberculosis (MDR-TB) financial protection policy: MDRTB health insurance schemes, in Chhattisgarh state, India. Health Economics Review [Internet]. 2018 [cited 2019 Apr 20];8(3):112. Available from: https://www.ncbi.nlm.nih.gov/pubmed/29374822

7. Fuady A, Tanja A, Houweling M, Burhan E, Richardus H. Effect of financial support on reducing the incidence of catastrophic costs among tuberculosis-affected households in Indonesia: eight simulated scenarios. Infect Dis Pov. 2019;8(10):1-14. https://doi.org/10.1186/ s40249-019-0519-7

8. Klein K, Bernachea MP, Iribarren S, Gibbons L, Chirico C, Rubinstein F. Correction evaluation of a social protection policy on tuberculosis treatment outcomes: a prospective cohort study. Plos Med. 2019; e1002788. https://doi.org/10.1371/journal.pmed.1002826

9. Lutge E, Lewin S, Volmink J, Friedman I, Lombard C. Economic support to improve tuberculosis treatment outcomes in South Africa: a pragmatic cluster-randomized controlled trial. BioMed Central [Internet]. 2013 [cited 2019 Apr 20];14(154):1-13. Available from: http://www. trialsjournal.com/content/14/1/154 
10. Wingfield T, Marco AT, Huff D, Boccia D, Montoya R, Ramos E, et al. A randomized controlled study of socioeconomic support to enhance tuberculosis prevention and treatment, Peru. Bull World Health Organ. 2017;95(1):270-80. https://doi.org/10.2471/BLT.16.170167

11. Rudgard WE, Chagas NS, Gayoso R. Uptake of governmental social protection and financial hardship during drug-resistant tuberculosis treatment in Rio de Janeiro, Brazil. Eur Respir J. 2018;51(1):1800274. https://doi.org/10.1183/13993003.00274-2018

12. Carter DJ, Daniel R, Torrens AW. The impact of a cash transfer programme on tuberculosis treatment success rate: a quasi-experimental study in Brazil. BMJ Glob Health. 2019;4:e001029. https://doi.org/10.1136/bmjgh-2018-001029

13. Santos-Reis B, Shete P, Bertolde A, Sales CM, Mauro NS, Arakaki-Sanchez D, et al. Tuberculosis in Brazil and cash transfer programs: a longitudinal database study of the effect of cash transfer on cure rates. Plos One. 2019;14(2):e0212617. https://doi.org/10.1371/journal. pone. 0212617

14. Torrens AW, Rasellab D, Bocciac D, Ethel LNM, Nerye JS, Olsonf ZD, et al. Effectiveness of a conditional cash transfer programme on TB cure rate: a retrospec tive cohor t study in Brazil. Trans Rev Soc Trop Med Hyg. 2016;110(1):199-206. https://doi.org/10.1093/trstmh/trw01

15. Moher D, Liberati A, Tetzlaff J, Altman DG. The PRISMA Group. Preferred Reporting Items for Systematic Reviews and Meta-Analyses: the PRISMA Statement. PLoS Med. 2009;6(7):e1000097. https://doi.org/10.1371/journal.pmed1000097

16. Galvão TF, Pansani TSA, Harrad D. Principais itens para relatar Revisões sistemáticas e Meta-análises: a recomendação PRISMA. Epidemiol Serv Saúde. 2015;24(2):335-42. https://doi.org/10.5123/S1679-49742015000200017

17. Santos CMC, Pimenta CAM, Nobre MRC. The PICO strategy for the research question construction and evidence search. Rev Latino-Am. Enfermagem. 2007;15(3):508-11. https://doi.org/10.1590/S0104-11692007000300023

18. Ouzzani M, Hammady H, Fedorowicz Z, Elmagarmid A. Rayyan: a web and mobile app for systematic reviews. System Rev. $2016 ; 5: 210$. https://doi.org/10.1186/s13643-016-0384-4

19. Melnyk BM, Fineout-Overholt E. Making the case for evidence-based practice. In: Melnyk BM, Fineout-Overholt E. Evidence-based practice in nursing \& healthcare: a guide to best practice. Philadelphia: Lippincot Williams \& Wilkins. 2010;110(5):41-7.

20. Hong QN, Pluye P, Fàbregues S, Bartlett G, Boardman F, Cargo M, et al. Mixed Methods Appraisal Tool (MMAT), version 2018 [cited 2019 Apr 20]. Available from: http://mixedmethodsappraisaltoolpublic.pbworks.com/w/file/fetch/127916259/MMAT_2018_criteriamanual_2018-08-01_ENG.pdf)

21. Moraes VD, Machado CV. O Programa Bolsa Família e as condicionalidades de saúde: desafios da coordenação intergovernamental e intersetorial. Saúde Debate. 2017;41(3):129-43. https://doi.org/10.1590/0103-11042017s310

22. Jakubowiak WM, Bogorodskaya EM, Borisov SE, Danilova ID, Kourbatova EV. Risk factors associated with default among new pulmonary TB patients and social support in six Russian regions. Int J Tuberc Lung Dis [Internet]. 2007 [cited 2019 Apr 20];11(1):46-53. Available from: https://pubmed.ncbi.nlm.nih.gov/17217129/

23. Andrade KVF, Nery JS, Souza RA, Pereira SM. Effects of social protection on tuberculosis treatment outcomes in low or middleincome and in high-burden countries: systematic review and meta-analysis. Cad Saúde Pública. 2018;34(1):e00153116. https://doi. org/10.1590/0102-311x00153116

24. Solar O, Irwin A. A conceptual framework for action on the social determinants of health: social determinants of health discussion paper 2 (Policy and Practice) [Internet]. Geneva: World Health Organization (WHO), 2010 [cited 2019 Apr 20]. Available from: https://www.who.int/ sdhconference/resources/ConceptualframeworkforactiononSDH_eng.pdf?ua=1 